\title{
Correction To: Quantifying the Likelihood of False Positives: Using Sensitivity Analysis to Bound Statistical Inference
}

\author{
Kyle J. Thomas ${ }^{1}$ · Jean Marie McGloin ${ }^{2}$. Christopher J. Sullivan ${ }^{3}$
}

Published online: 19 May 2020

(c) Springer Science+Business Media, LLC, part of Springer Nature 2020

\section{Correction To: Journal of Quantitative Criminology (2019) 35:631-662 https://doi.org/10.1007/s10940-018-9385-x}

Unfortunately, the subjected Special issue article has been inadvertently included in the regular issue volume 35, Issue 4 of this journal. We apologize for the error.

Publisher's Note Springer Nature remains neutral with regard to jurisdictional claims in published maps and institutional affiliations.

The original article can be found online at https://doi.org/10.1007/s10940-018-9385-x.

Kyle J. Thomas

thomaskj@umsl.edu

1 University of Missouri-St. Louis, 1 University Blvd, 331 Lucas Hall, St. Louis, MO 63121, USA

2 University of Maryland, College Park, MD, USA

3 University of Cincinnati, Cincinnati, $\mathrm{OH}$, USA 